\title{
Reflections on the Early Ceramic Period and the Terminal Archaic in South Central East Texas
}

James E. Corbin

Unknown

Follow this and additional works at: https://scholarworks.sfasu.edu/ita

Part of the American Material Culture Commons, Archaeological Anthropology Commons, Environmental Studies Commons, Other American Studies Commons, Other Arts and Humanities Commons, Other History of Art, Architecture, and Archaeology Commons, and the United States History Commons

Tell us how this article helped you.

This Article is brought to you for free and open access by the Center for Regional Heritage Research at SFA ScholarWorks. It has been accepted for inclusion in Index of Texas Archaeology: Open Access Gray Literature from the Lone Star State by an authorized editor of SFA ScholarWorks. For more information, please contact cdsscholarworks@sfasu.edu. 


\section{Reflections on the Early Ceramic Period and the Terminal Archaic in South}

Central East Texas

\section{Creative Commons License \\ (c) (i) (8)}

This work is licensed under a Creative Commons Attribution-NonCommercial 4.0 International License 


\title{
REFLECTIONS ON THE EARIY CERAMIC PERIOD AND THE TERMINAL ARCHAIC IN SOUTH CENTRAL EAST TEXAS
}

\author{
James E. Corbin
}

\begin{abstract}
The most significant shift in cultural adaptation in eastern Texas is generally attributed to the Caddoan cultures. Consequently, considerably more archaeology has been focused on the period from ca. A.D. 800-1750 than to the preceding 1000 years of culture change and adaptation. During this period, ceramics and the bow and arrow were incorporated into the subsistence tool kit of the indigenous Archaic cultures of the region. Demographic shifts on the landscape suggest that these societies were exploiting and/or settling on a different and/or greater range of environmental niches than the previous or subsequent societies. The archaeological record also suggests the Early Ceramic societies of the region were also participating in the wide-ranging trade networks that were extremely important factors in the success of the Caddoan societies that followed them.
\end{abstract}

\section{Introduction}

Long-term archaeological excavations at the Mast site (41NA157), a large Early Ceramic period site in central Nacogdoches County (Figure 1) in southern East Texas, is beginning to provide some insights into the societies of this temporal/cultural period. The site is entirely Early Ceramic in age, although it may not encompass the entire time span normally attributed to this archaeological complex. Sandy paste ceramics occur from the lowest cultural level to the surface of the site. Projectile point styles (Figure 2) shift from mediumsized Gary points and their normal associates to very small Gary points to, in the uppermost levels, arrowpoints in the Friley, Catahoula, and Scallorn milieu. Although most of the typical lithic tools and associated debitage are of local materials, scattered throughout the site are flakes, chips, and tools of various exotic materials. These include Catahoula sandstone, Edwards chert, Johns Valley chert, quartzites from the Uvalde gravels, Alibates chert, quartz, and one material geologists have not yet identified.

\section{Demographic Factors}

Topographic setting is an important consideration in East Texas and Early Ceramic period archaeology. The topographic setting of the Mast site is fairly typical of many sites of this time period (Figure 3), namely the end of an interfluve adjacent to the floodplain of a second- or third-order stream. In general, one can peruse a segment of the East Texas landscape and predict, to a large degree, the prehistoric cultural occupants of that landscape. Thus one can say that a specific topographic locale, based on our previous experience, will most likely have Archaic, Early Ceramic, or Caddoan cultural remains associated with it. In some cases, we can almost be certain that the cultural remains of only one of those broad cultural regimes will be on a particular bit of topography. Conversely, there are locales that will, to a large degree, have cultural remains related to the full sweep of the past 3-4000 years; that is, there are a few sites that contain the stratified remains of Middle Archaic through Caddoan occupations. Generally though, these sites tend to have much stronger Archaic and Early Ceramic deposits than they do Caddoan deposits. There 


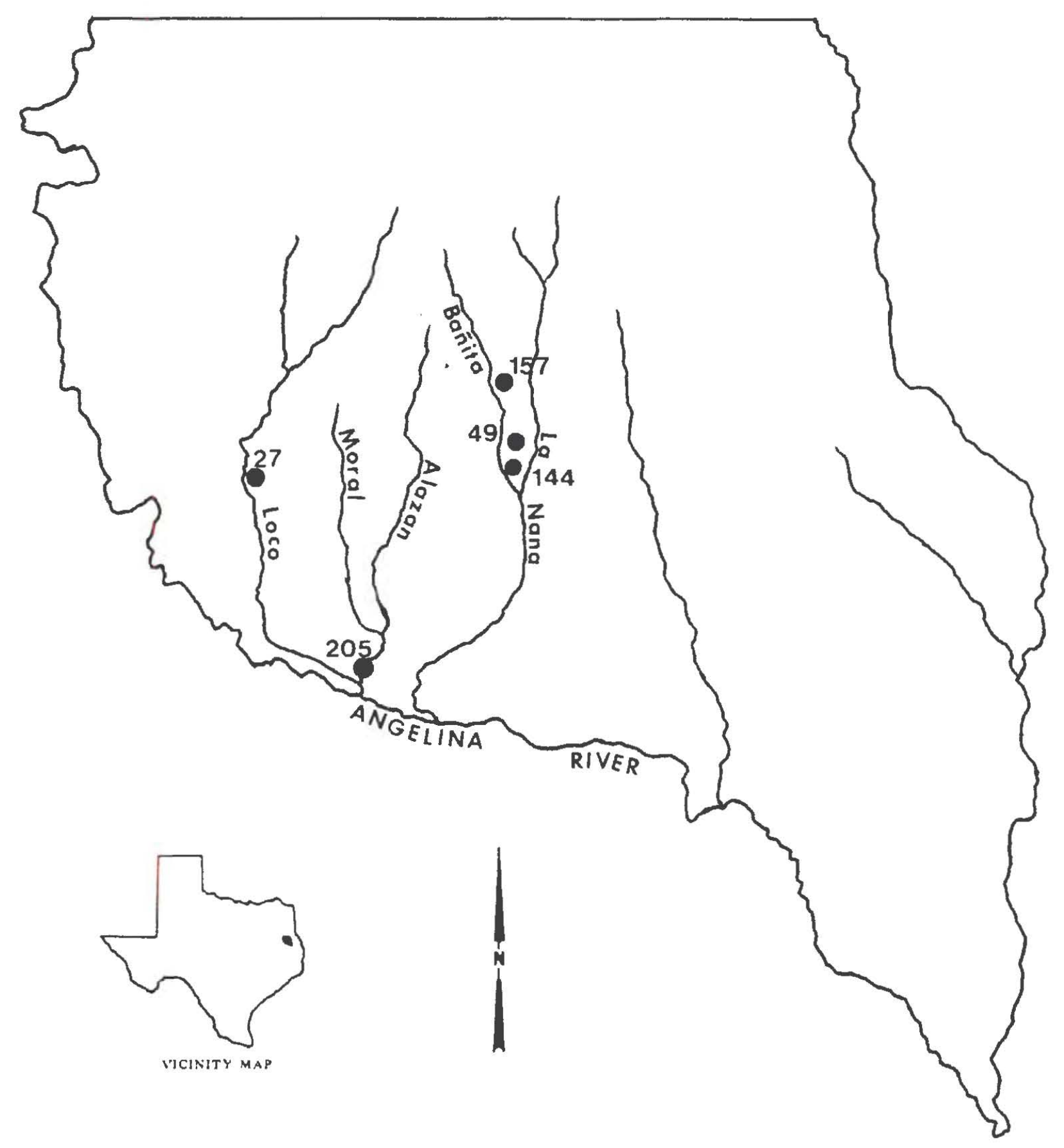

Figure 1. Location of the Mast Site and other Early Ceramic Period sites in Nacogdoches County 

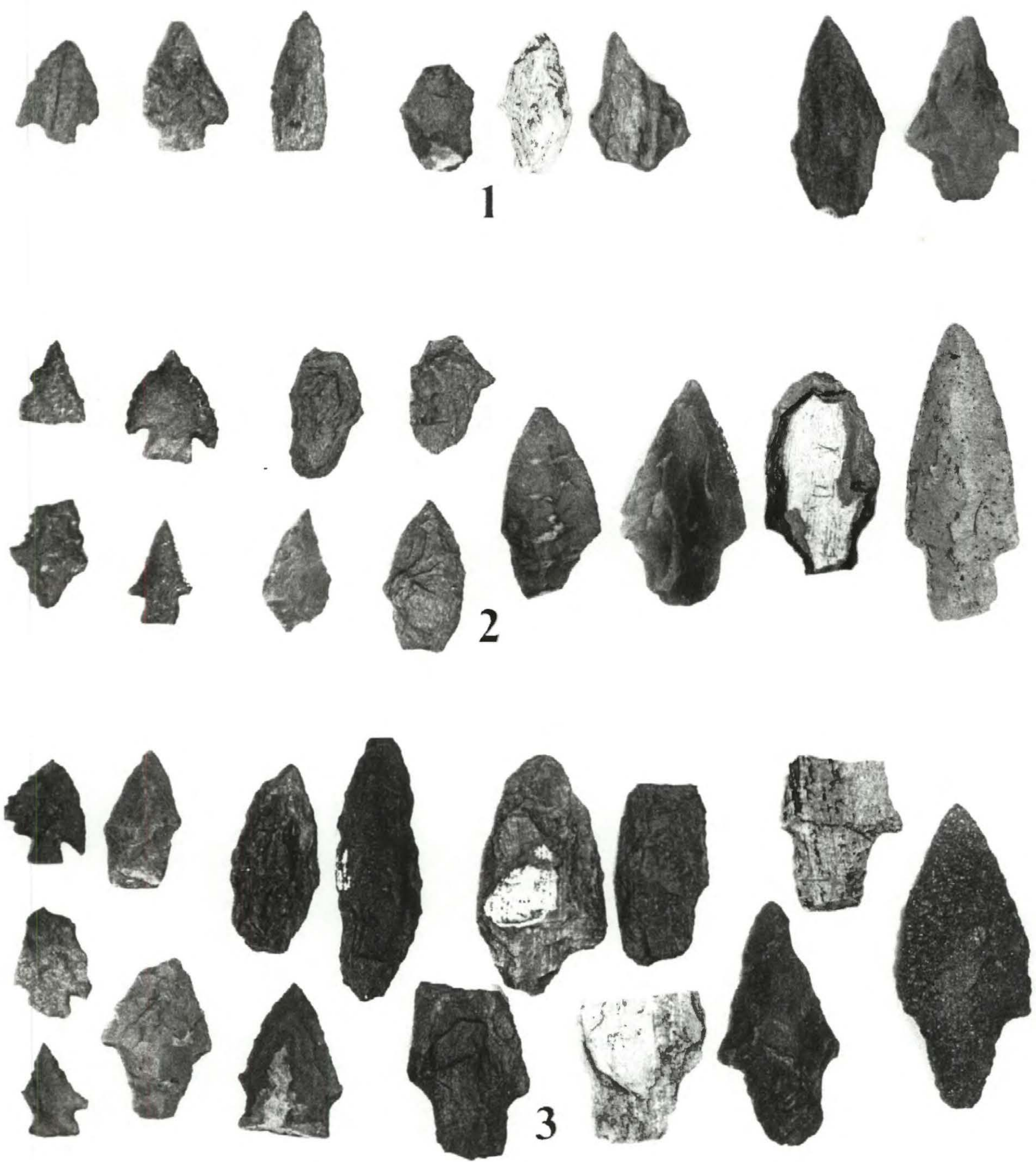

Figure 2. Projectile point styles and sequence at the Mast site (NA157). 


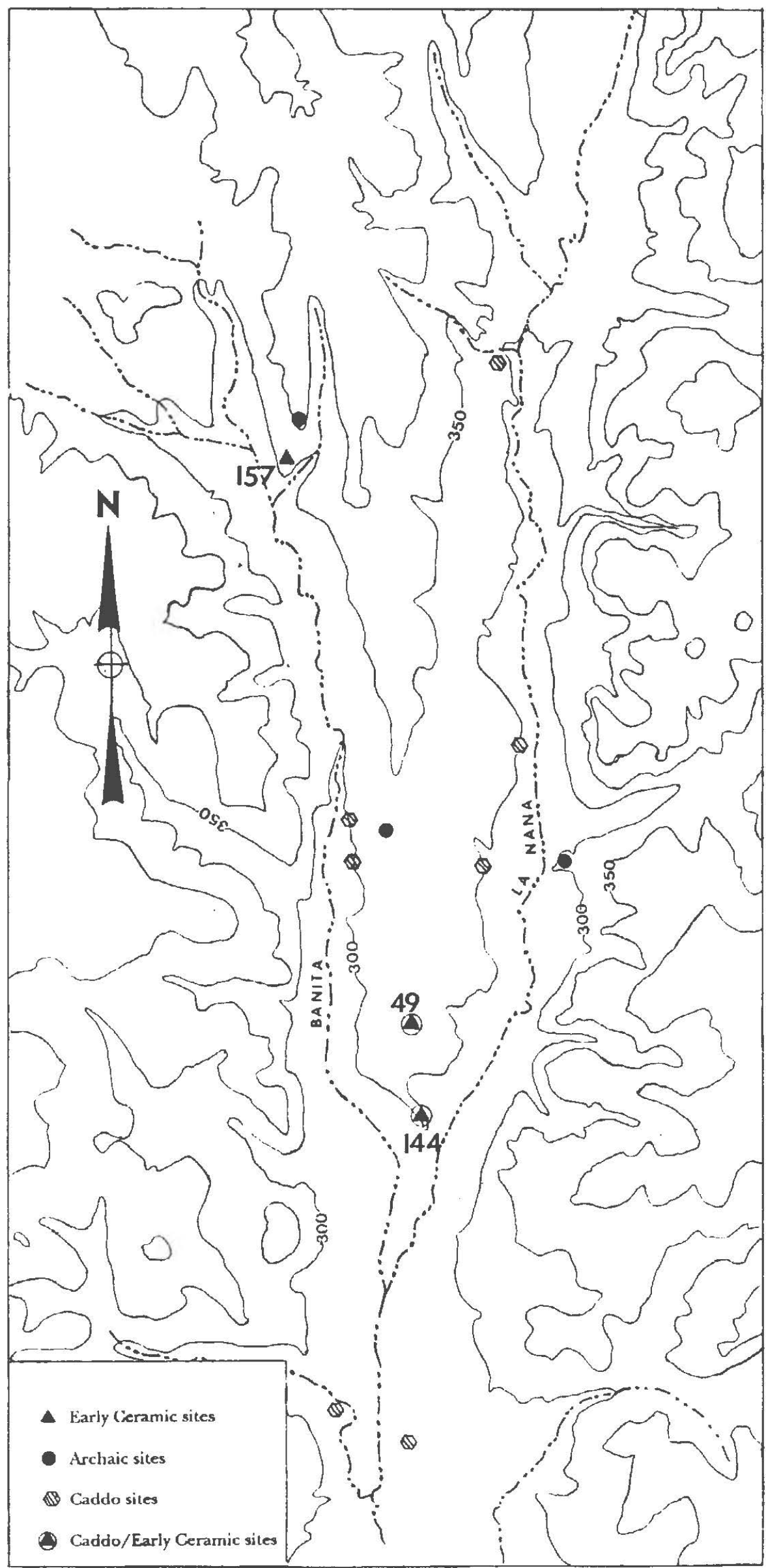

Figure 3. Early Ceramic period sites on the LaNana/Banita interfluve. 
are also sites that have only Archaic and Early Ceramic, or only Early Ceramic and Caddoan, cultural remains.

With this gross observation in mind, there is a temptation to make correlations between topographic setting and cultural adaptations. Without having the locations of, and the cultural affiliations of, all sites in the southern portion of East Texas, without including factors such as sites on landscapes that had not existed previously or sites that no longer exist, and without extensive paleoenvironmental data, it is somewhat risky to begin to make some assumptions about site placement and cultural adaptations, but models are just that: models.

If one starts at the south end of the small interfluve on which the Mast site is located and walks north, one is walking back in time. The Early Ceramic occupation is at the lower, sandy end of the ridge; artifacts indicate a progressively earlier occupation as one moves north. The known Caddoan sites are off of the ridge on sandy remnants at the edge of the floodplain or on sandy topographic features in the floodplain; some are on terrace-like features at the edge of the floodplain (if they are sandy), particularly if there is no usable topography in the adjacent floodplain. Archaeological sites along the central portion of the main north/south interfluve between La Nana and Banita creeks are primarily Archaic in nature until one reaches the southernmost portion of the ridge. Sites on the upland margins of the valleys are also primarily Archaic. Near the southern end of the interfluve is the Washington Square site (4INA49), a Middle Caddoan mound complex. While this site location is the exception to the rule, it is an exceptional site. In addition, the presence of the intersection of two main aboriginal trails may have as much or more to do with the location of this Caddoan site as other aspects of soil and topography. There is an Early Ceramic occupation in the same location. In fact, prehistoric occupation, mostly Middle and Late Caddoan and Early Ceramic, is fairly continuous from Washington Square at the end of the interfluve and the Sterne site (41NA144).

To continue the topographic assessment downstream to the Angelina River, we have to move west to a parallel set of streams because we have little or no survey data south of the juncture of the La Nana and Banita. Archaeological surveys on the lower reaches of the middle portion of Bayou Loco and the lower portions of the Moral and Alazan suggest topographic relationships similar to those for the middle and upper reaches of the La Nana and Banita. On the lowest portions of the Moral and Alazan bayous (Figure 4), near their juncture with the captured (within the Angelina River floodplain) Bayou Loco and its confluence with the Angelina, a series of surveys (Corbin 1978, 1994, 1995, 1997a, 1997b; Hubbard 1994) have revealed an interesting set of archaeological sites. These sites, so far only Late Archaic and Early Ceramic in age, generally occupy the expected topography. Interestingly, while one piece of topography within the marsh/floodplain will have cultural debris, a nearby locale, apparently no different, will have no evidence of human occupation. Unfortunately, the archaeology and geomorphology of the area have not been thoroughly investigated to determine why some topography is vacant and some is occupied. Three sites, on topography that one would have expected Caddoan cultural remains if anything, contained fairly dense Early Ceramic occupational debris. Two of these sites (41NA203 and 41NA204) are on small (ca. 20-30 m in diameter), very low ( \pm $20 \mathrm{~cm}$ ) sandy loam rises surrounded by marsh. The other (41NA205) is on a long, low sandy ridge adjacent to a relict stream channel, but also within very marshy terrain.

\section{Topography, Subsistence, Ceramics, and the Bow and Arrow}

Considering the above, I suggest that there is a loose topographic relationship between the appearance of ceramics, the diminution of Gary points, and the eventual replacement of dart 


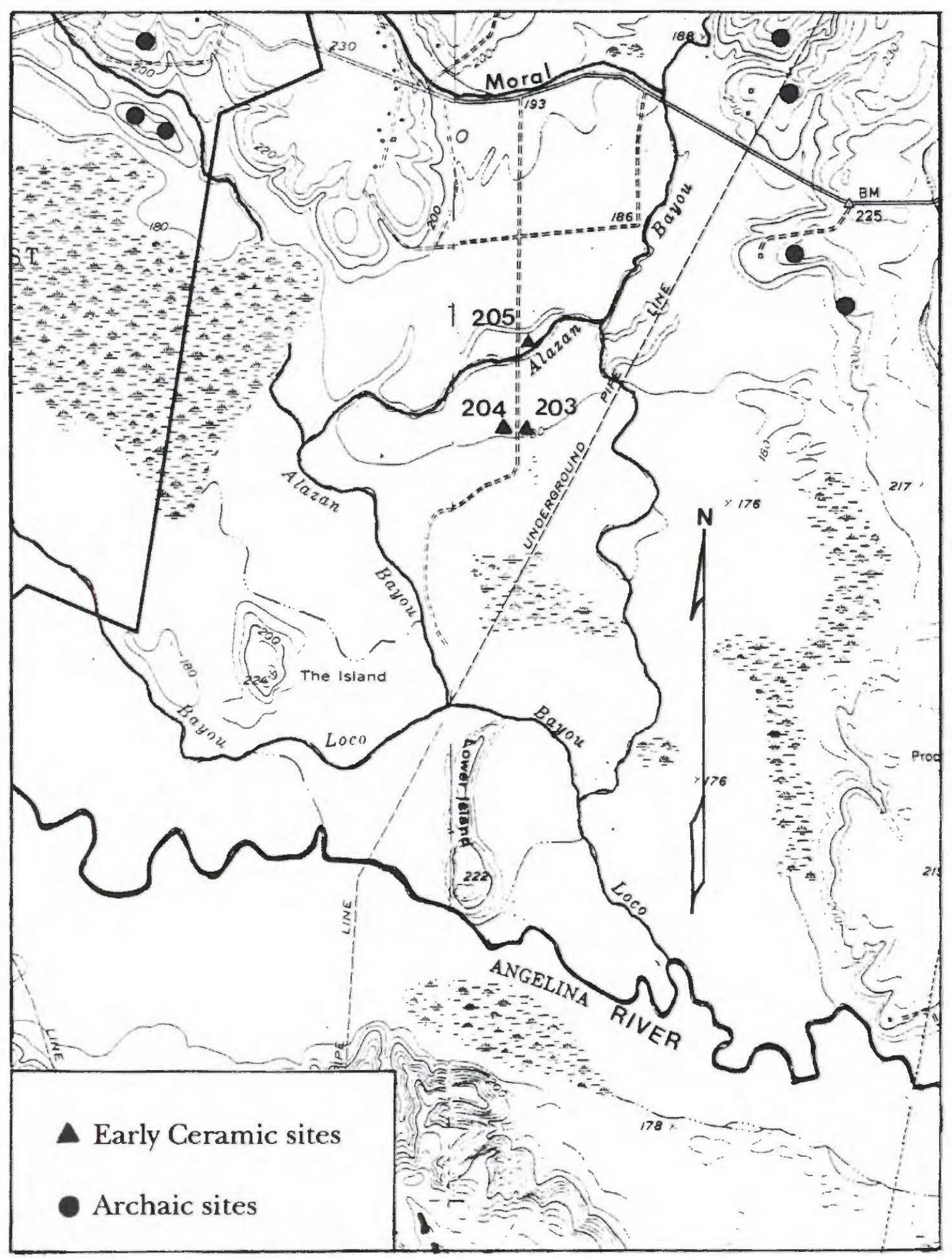

Figure 4. Early Ceramic Period sites along the lower Alazan, Moral, and Loco. 
points by Catahoula, Friley, Scallorn and various amorphous expanding stem arrowpoint forms. The shift from dart points to arrowpoints eventually triggers a shift in lithic reduction technology: from using the bipolar technique to produce cores that were then reduced to produce small dart points, to using the same technique to produce cores from which the flakes removed were chipped into small, thin, arrowpoints.

The stratigraphic sequence at the Mast site indicates clearly that ceramics preceded flake type arrowpoints, and that the diminution of Gary points (and some other types) to arrowpoint size begins after the introduction of ceramics (My hypothesis is that the diminution of the Gary point is the result of trying to produce an arrowpoint using a direct core reduction technology rather than a flake reduction technology). Coeval with the introduction of ceramics is a slight shift in site placement on the landscape and an increase in site frequency. While in general Caddoan sites never appear, if you wish, higher in elevation than Early Ceramic sites, many Early Ceramic sites occur at the same places as Caddoan sites, and it might appear, some Early Ceramic sites many be lower than Caddoan sites. While this last observation may well represent a difference in subsistence patterns, in the case of the sites in the marsh at Alazan, it may mean only that the marsh was not a marsh then or less marshy during Early Ceramic times, and/or much wetter during Middle and Late Caddoan times.

In the case of sites like Deshazo (41NA27), Washington Square, and Sterne, where Early Ceramic people and the later Caddoan people occupied essentially the same turf, one wonders if the occupations were there for the same or different reasons. We assume the Caddos were there, for the most part, because it was a good place for farmers. Could it be the same for the Early Ceramic people as well? At Deshazo, there is even a hint that Caddos were out there somewhere (but not at Deshazo) while the Early ceramic people were there. At Mast, there is a good, strong Early Ccramic occupation, but no Caddoan and no Archaic. Why was this a good place for Early Ceramic people, but not Caddos or the preceding Archaic cultures?

On stylistic grounds, it is logical to surmise that at least portions of the Early Ceramic occupations at Mast, Washington Square, Sterne, Deshazo, and the Alazan marsh sites were contemporaneous. Thus, they were occupying three very different locations on the landscape, two of which (Mast and the Alazan sites) were not occupied by the later Caddoan cultures, at least not at those locations. In the case of the Early Ceramic people, there is a suggestion of a more dispersed, or perhaps more diverse, settlement pattern than the later Caddo groups. It would also appear that these sites indicate a more dispersed or, again, more diverse settlement pattern than the preceding Archaic cultures. This is not to say that the Archaic or Caddoan cultures did not exploit those environmental niches, but if they did, they were not there long enough to leave easily identifiable traces.

In the Alazan/Moral/Loco bayou floodplain/marsh locales, there are other sites on fairly prominent sandy rises and ridges. Although not investigated thoroughly, some of the sites on the uplands adjacent to the floodplains are clearly large Late Archaic sites. Others appear to be thin scatters of lithic debris, primarily small flakes. In the limited shovel testing of these sites, no diagnostic materials (i.e., projectile points or ceramics) were recovered. Given that the flake density was no less dense than the nearby Early Ceramic sites or in Caddoan sites upstream, it is assumed that these sites might in fact be Archaic.

Given that we accept for the time being that the shift in topographic distribution of sites may represent adaptive shifts, it now remains to reflect briefly on the apparent shift in tool assemblages that mirror site distributions. As noted above, two things tend to co-occur with site placement: the introduction of ceramics and, eventually, the introduction of the bow and arrow. It would seem that the introduction of the bow and arrow had little to do 
with demography other than as a more efficient hunting tool, it may have allowed the acquisition of more game and/or a greater variety of game, thus providing more food. Yet since the bow and arrow comes after (although for the present we do not know how long after) ceramics and the shift on the landscape, this tool introduction is not seen as being significant in that respect.

Since the sites preceding the Early Ceramic sites appear little different in terms of tool kits, and the introduction of ceramics seems to be an addition to the existing took kit, it would appear that the appearance of sandy paste ceramics and the subsequent demographic shift are significant. Ceramics and an associated cooking technology might well affect demographic factors, i.e., allow the processing of foodstuffs not previously accessible. This would hardly seem any more significant than the bow and arrow in terms of increasing food supply, although together they could bring about a very significant increase in energy reflected in a higher and probably more dense population. Yet, unless the plants acquired and processed are intimately tied to a lower topography and it is just more convenient to have your habitation closer to the source in terms of processing large masses of plant foods, it seems that just the introduction of ceramics, if not tied to some other factor or factors, would not be sufficient to trigger the topographic move.

To this author, the occurrence of Early Ceramic sites on locales later used by Caddoan folks is more significant than Early Ceramic sites occupying some locales, albeit close to Caddo topography, utilized by preceding Archaic cultures. Thus, we might hypothesize that some form of horticulture was introduced along with the ceramics, an activity that utilized the lower topographic situations and required a topographic shift of settlements. On the other hand, the shift could have been due to some large scale environmental factor (e.g., lower rainfall, thus more xeric conditions) that forced the Early Ceramic people to shift their settlements. The shift might have been tied to just moving closer to a significant plant food source (i.e., plants that were restricted to valley margins and/or the floodplain) whose use was facilitated by processing via cooking in ceramic vessels. At this point, it is not known if these factors, a combination of these factors, or unknown factors were involved. Thus, we are left with the question: were the Early Ceramic cultures Archaic (i.e., primarily food collectors), Transitional (i.e., a combination of food collectors and horticulture), or incipient Formative (i.e., developing a sedentary life style based on agriculture and/or some other form of subsistence that allowed a more sedentary or largely sedentary lifestyle)? Only more archaeology will give us the answers, but Early Ceramic archaeology, not Caddoan or Archaic archaeology.

\section{References Cited}

Corbin, J. E.

1978 Archaeological Survey for Angelina-Nacogdoches Regional Airport Master Plan Study. Letter report submitted to Turner, Collie \& Braden, Houston.

1994 Archaeological Survey of a Proposed Trail System and a Parking Lot in the Stephen F. Austin Experimental Forest, Compartment 112, Angelina National Forest, Nacogdoches County, Texas. Archaeological Survey Report No. 94-35, Nacogdoches.

1995 Archaeological Survey of a Proposed Road and Parking Area Construction Project in the Alazan Bayou Wildlife Management Area, Nacogdoches County, Texas. Archaeological Survey Report No. 95-14, Nacogdoches. 
1997a Archaeological Survey of a Proposed Road and Parking Area Construction Project in the Alazan Bayou Wildlife Management Area, Nacogdoches County, Texas. Archaeological Survey Report No. 97-1, Nacogdoches.

1997b Cultural Resource Assessment of the Proposed Ducks Unlimited Wetlands Restoration Project in the Alazan Bayou Wildlife Management Area, Nacogdoches County, Texas. Stephen F. Austin State University, Nacogdoches.

Hubbard, V.

1994 CulturalResource Survey of the Proposed Stephen F. Austin Experimental Forest Trail System, Compartment 112, Angelina National Forest, Nacogdoches County, Texas. U.S. Forest Service, Lufkin. 


\title{
POR LAS ESPALDAS SE NOS VAN ENTRANDO CON SILENCIO' ${ }^{\text {: }}$ FR. HIDALGO'S LETTER TO THE VICEROY
}

\author{
Mariah F. Wade
}

\begin{abstract}
The translation of historical documents is essential to the practices of archaeology and ethnohistory. The present translation presents the complete text of a letter written by Fray Francisco Hidalgo to the Viceroy of New Spain on November 4,1716 . This translation strives for accuracy and adds contextual information to enhance the value of the document. Fray Hidalgo's letter exemplifies how Spanish officials acquired information about the French and the various Native groups, and how they viewed their interrelationships, actions, and customs. It confirms that Fr. Hidalgo did write two letters to the French officials in Louisiana, includes important floral and faunal information, provides locations for the Apache and Pawnee, and states that Diego Ramon traveled to the Mississippi River and visited Mobile. The epistle provides information on the geo-political and economic paradigms of the time, and how they shaped Spanish policy.
\end{abstract}

\section{Introduction}

The early history of the relationships between Spanish friars and Native American groups, in what is today northern Mexico and Texas, does not portray a vehement repugnance on the part of the Native Americans to accept the Catholic faith. The Caddo groups of East Texas were the exception. Starting in 1691 and at various times afterwards, Franciscan friars supported by the military actively tried to Christianize Caddoan-speaking groups. They were ignored, rebuffed, and twice expulsed. Although the Caddo asked and actually invited the Spanish and their friars into their lands, they quite emphatically refused their religion. The Caddo accepted the Spanish presence, welcomed their trade, and played them against the French, but most abstained from Catholic religious practices. It is possible that researchers have not completely understood the essence of this refusal nor the strength of Caddo religious practices and convictions.

Fr. Francisco Hidalgo was undoubtedly the principal force behind the return of the Spanish to Caddo country in $1716^{2}$. To return to the Tejas country, he exploited and profited from the continuous strong-arm contest between the Crowns of Spain and France. Fr. Hidalgo was an experienced and crafty politician who, by his own admission, had made an agreement with Bernardino in 1691, when the Spanish first tried to settle Caddo country. Bernardino was one of the principal leaders of the Tejas. According to this agreement, Fr. Hidalgo had promised to return to East Texas whenever circumstances allowed it. Fr. Hidalgo clearly believed the Tejas ${ }^{3}$ wanted the presence of the Spanish and were willing to undergo the process of Christianization. The peremptory order given by Tejas leaders to the Spanish to abandon their territory proves that he was mistaken.

What follows is the translation of a letter Fr. Francisco Hidalgo (1716) wrote to the Viceroy ${ }^{4}$ in November 1716. The letter was written at the Spanish Mission of San Francisco de los Tejas which had just been re-established by Fr. Hidalgo near the Neches River. This letter was translated by Mattie Austin Hatcher and published in the Southwestern Historical Quarterly (Hatcher 1927:53-62). Hatcher's translation has some omissions and, at times, she appears to have misconstrued some of the meanings. In 1942, 